\title{
ЧЛАНЦИИ РАСПРАВЕ
}

Проф. др Драган Милков

професор IІравног факултета у Новом Саду

\section{ДОКАЗИВАЊЕ У УПРАВНОМ ПОСТУПКУ}

\section{1. Опште напомене}

У управном поступку, као и у другим правним поступцима, постоји фаза поступка намењена утвр)ивању чињеница. Та фаза у управном поступку показује одређене разлике у односу на судске поступке, а у случају воһења скраһеног поступка се о предмету непосредно одлучује на основу акта о похретању поступка, односно захтева странке. То значи да се у целини изоставља посебан испитни поступах, па нема ни посебне фазе доказивања Нмајуһи у виду да се највеһи број управних ствари решава у скраһеном поступку, јасно је да посебна фаза дохазивања нема у управном поступку ни приближно такав значај какав има у судским поступцима.

С обзиром на то да доношење одлуке у свахом поступку зависи од одређених чињеница и околности, јавља се потреба за њиховим утврһивањем. Орган хоји води поступах може утврдити чињенично стање само ако се увери у постојање одређених околности и чињеница које граде чињенично стање. Таква активност опгана и странака, усмерена на стицање уверења о постојању одређених чињеница и околности, назива се доказивањем.

Под доказивањем се подразумева укупност процесних радњи органа и странака које имају за иињ стицање уверења о постојању одреһених чињеница и околности од којих зависи доношење одлуке. Основна сврха доказивања је да службено лице које води поступах стекне потпуно уверење о истинитости тврдњи о постојању или непостојању чињеница и охолности ${ }^{1}$. Према томе, у поступку доказивања треба да се

1 Нехала се као цил доказнвана помнње „утврһнвање истинятости правно релевантних чнненяца" (ул. С. Ilоповиһ, Управно право, Београд 1992, стр. 592). Меһуттм, чнњенице представљају део објектнине старности н не могу бнтн „нстините" нли "некстините". Једино наше тврдње н сазнаңье о чиненниама могу бнти нстинити нли ненстинити. 
утврди да ли неке чињенице и охолности постоје (чиме се проверавају тврдње странке или претпоставке органа о њихово постојању), као и какве су. На основу тога се доноси одлука у поступку, која може бити позитнвна или негативна. Стога је правилна примена материјалног права у директној зависности од правилности утврһнвана чньеннчног стања. Грешке учињене у вези са доказивањем представљају основ за жалбу, као и за воһене управног спора.

Чињенише релевантне за доношење одлуке се утврҺују уз помо других чнњеница, које се зову доказима Доказ (probatio) или доказно средство (insmumentum) представља сваку чнњенииу (процесно средство) на основу хоје се може проверити постојање чињеница и околности битних за доношење одлуке. Доказима се проверава истинитост тврдњи странке или претпоставки службеног лища о постојању релевантних чнњеница и њнховој садржини.

\section{2. Предмет доказнвања}

Под предметом доказивања (thema probandi) се подразумевају чињенице које треба доказивати, од којих зависи примена материјалног права у сваком конкретном случају. ${ }^{2}$ Предмет доказивана у управном поступку је постојање и садржина спорних и правно релевантних чињеница. Према томе, доказује се само оно што је битно за решаване конкретне управне ствари (правно релевантне чиненице), али не све од тога, него само оно што је спорно.

Према Захону о општем управном поступку, о томе да ли неху чнњеницу треба доказивати одлучује службено лище које води поступак, спрам околности да ли та чињеница може имати утицаја на решавање ствари'. Одговор на питање које су чнњенице правно релевантне, службено лице һе добити анализом садржине материјално-правних прописа који се односе на конкретан случај. Но, службено лице неһе доказнвати све правно релевантне чнњеннце, него само оне од њих хоје су спорне (fastidum est in rebus manifestissimis probationes adducere - лудост је у потпуно јасним стварима изводити доказе). Да ли су неке чиненице спорне или нису, о томе одлучује службено лице. Спорне су оне чнњенице за чије постојање и садржину службено лице нема извесно и несумњнво уверење.

Оне чињенице хоје нису спорне се не доказују. У посе6ну групу неспорних чињеница спадају општепознате (ноторне) чияенице. Hоторне чињенице никада не треба доказивати (notorium non egct probati-

2 Нехн ауторн смаграју (уп. Трняя Граһансхо парикчно проиесно право, 3агре6.

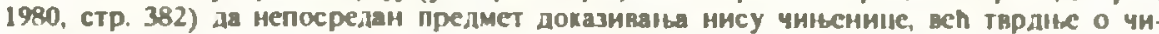
њеницама Чньенние су само посрелан прелмет догазивана хроз пропру истинитости тардње о њиховом постојању и салржини. Оя теза је несумњиво тачна, али је ствар хонвенинје што he се нстнцатн у прном плану: посредан или непосредан предмет догазнвана

3 Закон о опитем управном поступку (пречншиенн техст), „Службени лнст СОР" , 6р. 47 од 15. августа 1986. годнне, чл. 160. 
one). У ЗУП-у није прецизирана садржина појма ноторних чињеница (као да је појам ноторних чињеница ноторан), тако да службено лице мора о томе одлучивати у свакој конкретној ситуацији. У сваком случају, ноторне чињенице могу бити само оне које су познате ширем кругу људи у средини у којој се води управни поступак. Но, о томе не постоје строга правила, тахо да се понекад хао ноторно узима и оно што је познато ужем кругу људи, мада се никада као ноторно не може узети оно што је познато само органу који води поступак, или поједином службеном лицу'. Меһутим, странка увек има могуһност да побија „ноторност” неких чињеница и да доказује да нека чињеница није општепозната Тада се мора спровести редован поступах дохазивања С обзиром на специфичности управног поступка, ноторне чињенице се јављају релативно ретко. То би нпр. могао бити случај са пореским поступком, у коме се као основ за ослобоһење од пореске обавезе може узети као ноторно то да су поплавом у одређеном крају уништени сви усеви.

Поред ноторних чињеница, у управном поступку се не морају доказивати ни законске претпоставке (praesumptiones iuris). Чињенице чије постојање закон претпоставља, не треба доказивати 6 . Захонске претпоставке представљају правна правила закључивања о постојању одреҺених правно релевантних чињеница, на основу стварног постојања других чињеница које нису релевантне, али су са њима у вези (на основу чињенице што је нехо муж мајке, постоји правно правило закључивања да је то лице отац детета). Законске претпоставке су изграђене на основу искуства типичног за одређене случајеве и велике вероватноһе да се оно што се претпоставља поклапа са стварношиу. Меңутим, претпоставке у нашем праву спадају по правилу у категорију оборивих, релативних претпоставки (praesumptiones iuris tantum), тако да је допуштено доказивање њиховог непостојања, осим ако законом није другачије одреһено (тада би биле у питању необориве, апсолутне претпоставке - praesumptiones iuris et de iure). Tерет доказивања нетачности онога што се претпоставља пада на оно лице које то оспорава Доказ је јачи од претпоставке (probatio vincit pracsumptionem).

Предмет доказивања представља једино постојање чињеница, а не и правних правила. Претпоставља се да орган хоји води поступак познаје садржину правних правила, тако да их не треба доказивати. У управном поступку важи аналогна претпоставка као за судове (iura novit curia). Меһутим, та претпоставка важи за домаће, а не и за страно право. у случају да органу који води поступак није познато страно право, може се о томе обавестити ход савезног органа надлежног за послове правосуһа. Исто тако, орган може од странке тражити да поднесе јавну исправу издату од надлежног страног органа којом се потврһује које право важи у страној држави, с тим што се може доказивати и супротно од

4 В. C. Половнh op.cir., cтр. 593; С. Трнва, ор. cï, стр. 384-385.

5 Ако су неке чнњенние познате органу којн водн поступах, то може, по члану 141. ЗУІ1-в, бнтн основ 39 воһење схраһеног улравног поступка.

- Закон о опитем управном поступху, чл. 160, став 3 . 
садржине ове исправе, осим ако није меһународним уговором другачије предвиҺено. Према томе, садржина страног права се по правилу посебно утврһује (нпр. у поступку одлучивана о натурализацији се сматра да је испунен услов о отпусту из ранијег држављанства, ако hе лину које тражи југословенско држављанство аутоматски престати раније држављанство у тренутку када стекне југословенско држављанство; но, да ли је тако по праву државе чији је држављанин лице које тражи југословенско држављанство, то наш орган не мора познавати). Мећутим, и претпоставка да орган који води поступак познаје домаһе право, није нешто што се не може оспоравати. Напротив, погрешна примена права (која може наступити и због незнања!) представља основ за жалбу, ванредна правна средства и воһење управног спора.

Сматра се да је циљ доказивања постигнут онда кад је орган којн води поступак дошао до таквог степена уверења о постојању одређених чињеница и околности да о томе не постоји више никаква суміьа Доказано је онда када постојн потпуна извесност о постојању и садржини релевантних чнњеница Меһутим, према Закону о општем управном поступку се овакав степен извесности не тражи увек. Лрописима може бити предвияено да се управна ствар може решити и на подлози чињеница или околности које нису потпуно доказане или се доказима само посредно утврҺују. То су чнњенице и околности које се не морају потпуно доказати, већ је довољно да се њихово постојање учини вероваTHIM ${ }^{7}$.

Вероватност представљ блажи степен извесности постојања неких чињеница. Вероватност постоји ахо има више аргумената који говоре у прилог постојања неких чиненица и околности, од аргумената који говоре против, мада о томе не постоји никаква дефиниција у $3 У П-y^{8}$. Но, у сваком случају, о томе да ли су неке чињенице учињене вероватним, одлучује службено лице које води поступак, имајуһн у виду све околиости конкретне ситуације (такав степен извесности се, према ЗУП-у, тражи код изузеһа службеног лища, ван апсолутних разлога; исто тако, вероватност је предвиђена код захтева за повраһај у преһашье стазье; хада странка захтева обнову поступка и сл.). Осим степена извесности, измепу вероватности и доказаног постојн и разлика у поступку. Поступак доказивања одређених чињеница и околности је прецизиран у ЗУП-у, али те норме не везују службено лице ако неке чињенице треба само учннити вероватним. Службено лище тада ужыва веһи степен слободе.

У погледу органа пред којим се врши доказивање, правило је да се то чини пред оним органом гојн води целокупан поступак. Меһутим, ако је доказивање пред њим неизводыно, повезано са несразмерним трошковима или са великим губитком времена, доказивање или поједини докази могу се изводити и пред замољеним органом. То се онда чини у виду правне помоһи, а основни разлог да се тако поступи налази се у остварнвању начела економичности и ефикасности или, пак, постоји објективна немогуһност да се другачије поступи.

\footnotetext{
Захон о опнтем упрапном поступку, чл. 162

B B. C. Monoshh op. cis., ctp. 596.
} 


\section{3. Терет доказивања}

Под теретом доказивања се подразумева дужност изношена чињенища и околности (доказа) који служе за утврһиване правно релевантних чињеница. На коме је терет доказивања, зависи од система који је усвојен у вези са прикупљањем чињеница У том смислу се разликују расправно и истражно начело.

У управном поступку је прихваһена комбннација расправног и истражног начела, са нагласком на истражном начелу, па се, у складу са тим, иста констатација може учинити и везано за терет доказивања. Нанме, службено лице је дужно да предузима иницијативу у погледу утврһивања чињеница, али се и од странке тражи да уз своје наводе поднесе или бар понуди доказе, као што јој се увек омогуһава активна улога у процесу доказивања. Странка је увек дужна да чнњенично стање на коме заснива свој захтев изнесе тачно, истинито и одређено. Уз своје наводе, странка је дужна да понуди доказе и да их по могуиности поднесе, осим ако су у питању општепознате чиьенице. Ако странка не поступи сама тако, службено лице које води поступак he је позвати н оставити рок у коме то треба да учини. Меһутим, протек рока не доводи до аутоматског одбацивања захтева странке, већ је орган дужан да настави воһење поступка и реши конкретну ствар у складу са прописима (крајњи исход, свакако, може бити негатнван по странку). С друге стране, од странке се неһе тражити да прибави и поднесе доказе које брже и лакше може прибавити орган који води поступак, као ни да подноси таква уверења која органи не издају на основу службене евидениије. Исто тако, предвиђена је обавеза органа да по службеној дужности прибави податке о чињеницама о којима води евиденцију тај или други орган.

Формално посматрано, дакле, не може се прецизно рећи на коме је терет доказивања. али се зато може говорити о ономе што се у немачкој теорији назива објективним или материјалним теретом доказивања". Наиме, без обзира на то што терет доказивања није формално утврђен, објективно посматрано, он је на ономе коме би неразјашњеност чињеничног стања била на штету или, познтивно речено, на ономе ко би од разјашњеног чињеничног стања имао користи ${ }^{10}$. Ако би то било на штету јавног интереса, тада бн објективно веһа иницијатива била на органу који води поступак, и, обрнуто, ако би то било на штету странке, онда се она мора трудити да се чиненично стање потпуно утврди и разјасни. Практично, веһн терет би бно на органу ако је поступак усмерен на нздавање обавезујуһег управног акта, а на странци ако је усмерен на издавање овлашhyјyher управног акта. Но, оваква „подела" терета доказивања је само типична, а не и апсолутна.

143.

9. Ule-Laubinger, Verwolsungorerfuhrenorechı, Köln-Berlın-Bon-München, 1979, стр.

10 I Іосматрајуһн положај странхе у парнини. Трняа нстиче да „дужност нзионсна чнненица и предлаганя доказа не прелстая қа обавезу према пврничном протнвнику а ни према суду, всһ. у суитнин, спенифичну обавезу према самом себм. Ilреллаганем ефикасннх доказа странка остварује повахне изгледе за свој успјех у парнини. 36ог тога се у теорнјн процесног правя ова дужност радије нззнва теретомнего обавсзом“" (ор. сіь., стр. 395). 


\section{4. Доказна средства}

Под доказним средствнма се подразумева извор сазнања о постојању и садржини правно релевантних чињеница. Доказна средства су све чињенице, односно процесна средства, помоһу којих се утврһује предмет доказивања. Доказна средства нису у Закону о општем управном поступку таксативно набројана, тј. не представљају затворен круг, Beh cy наведена само најчешhа и најтипичнија доказна средства.

у Закону о општем управном поступку је, најпре, општом формулацијом одређено да се у управном поступку као доказно средство може употребити све што је подесно за утврђивање стања ствари и што одговара поједином случају. " У том погледу, дакле, службеном лищу које води поступак нису одрећене никакве границе. Меһутим, ипак су набројана најтипичнија доказна средства, а то су: исправе, односно микрофилмске копије исправе или репродукција те копије, сведощи, изјава странке, вештаци и увыңај. То значи да би, поред набројаних доказиих средстава, могло бити употребљено и било које друго доказно средство, ако би бнло подесно у конкретном случају (нпр. фотографски, филмски или магнетофонски снимци, под условом да су прибављени на закоиит начин).

У теорији се понекад, с правом, истиче да сведоци и вештаци, строго посматрано, ннсу доказна средства (ради се о физичкнм лицнма), Beh да су то њнхове изјаве, односно налаз или мишљење. У том смислу се у Закону о општем управном поступку прави разлика измеһу странке и њене изјаве, па се само ово последње сматра доказним средством. Нсто тако би требало поступити и са сведоцима и вештацима, па доказним средством сматрати изјаву сведока, малаз или мишљење вештака. С друге стране, тврди се да би своһење доказног средства само на изјаве сведока, односно вештака, водило занемаривању чињенице да ова лица тек као целовите особе, па и својим изјавама, представљају целовит скуп информација, на основу којих службено лице закључује о значају информација које му они пружају'2. Нсто тако, у теорији се понекад и увнһају одриче карактер доказног средства. Нанме, увиһај је прощесна радња усмерена на испитивање предмета увиһаја који су, у ствари, доказно средство.

У nогледу доказне снаге, у Закону о општем управном поступку се не прави никаква разлика, нити се поједини докази фаворизују на рачун других. Службено лице самостално одлучује о томе, ммајуии у виду начело слободне оцене дохаза. Исто тако, у управном поступку не постоје никаква правила ни о редоследу извоһења доказа. Који докази, како и у ком редоследу hе се извести. о томе одлучује службено лице које води поступак, водеһи рачуна једино о томе да се доһе до материјалне истине. Једини изузетак је предвиһен, у одреһеном смислу, везано за изјаву

11 Закон о опитем упранном поступку, чл. 159. став 2

12 В. Трнвя, ор. cu., стр. 391. 
странке $^{13}$. Ово доказно средство је супсиднјарног карактера и може.се употребити ако за утврһивање одреһене чињенице не постоји непосредан доказ или се таква чињеница не може утврдити на подлози других доказних средстава. Поред тога, усмено дата изјава странке се може узети као доказно средство и у стварима малог значаја, ако би се одреһена чињеница имала утврһнвати саслушањем сведока који живн у месту удаљеном од седишта органа или би нначе, услед прибављања других доказа, било отежано остваривање права странке. Тиме се посредно изјава странке третира као непоуздано доказно средство.

\section{Уместо закључка}

Доказивање у управном поступку има сличности са доказивањем у судским поступцима, али и значајних разлика. Нормативно посматрано, могао би се стеһн утисак да је доказивање у управном поступку веома слично доказивању у судским поступцима. Тај закључак, ако се остане на нормативном нивоу, није нетачан, јер је управни поступак стваран по узору на парнични поступак. Меһутим, многе норме Закона о општем управном поступку немају своју примену у пракси. Пре свега, за управни поступак је карактеристично да се управне ствари најчешһе решавају у скраһеном поступку, у коме нзостаје посебна фаза доказивања, тако да све одредбе о сведоцима, вештацима, усменој расправи и сл., готово да се у пракси ни не примењују. Најчешһе странха уз свој захтев поднесе све што је потребно за одлучивање или надлежни орган, када поступак покреће по службеној дужности, располаже неопходним подаиима, тако да се одмах, у скраһеном поступку, приступа одлучивању. Поред тога, одреһене разлике постоје и у погледу предмета доказивања, терета доказивања и доказних средстава.

Предмет доказивања у управном поступку је постојање и садржина спорних и правно релевантних чињеница Према томе, доказује се само оно што је битно за решавање конкретне управне ствари (правно релевантне чињенице), али не све од тога, него само оно што је спорно. Не доказују се ноторне чињенице, као ни правне претпоставке, а у неким случајевима се неке чињенище и околности ни не морају доказати, него само учинити вероватним.

Терет доказивања у управном поступку је подељен измеһу службеног лица и странке, при чему је службено лице дужно да предузма иницијативу у погледу утврһивања чнњеница. Формално посматрано, не може се прецизно рећи на коме је терет доказивања, али се зато може

13 Изјава странке је код нас као доказно средство уведена нзменама и допуиама Закона о општем управном поступку из 1965. годнне. У Немачкој је предвиһена општа обавезя странака да сараһују са органом у погледу утврһнван чннениша алн обавсзу давања нзјаве страние нмају само ато је то нзрнчнто предвнһено посебним прописнма. У IIIпанском 3УІІ-у се ово доказно средство уопште не помнье, а у Аустрнјн је давањс нзјаве изједначено са обавезом сведочена и може се избсни под истии условима којнма свсдок може бнти ослобоһсн дужности сведочена 
говорити о ономе што се у немачкој теорији назива објективним или материјалним теретом доказивања Објект ивно посматрано, терет је на ономе коме би неразјашњеност чињеничног стања била на штету или, позитивно речено, на ономе ко би од разјашњеног чињеничног стањь имао користи.

Доказна средства нису у Закону о општем управном поступку таксативно набројана, тј. не представљају затворен хруг, већ су наведена само најчешhа и најтипичнија доказна средства. То су: исправе, односно микрофилмске копије исправе или репродукција те копије, сведоци, изјава странке, вештаци и увиһај. Поред тога, у управном поступку као доказно средство може бити све што је подесно за утврһивање стања ствари и што одговара поједином случају. 